\title{
IRON METABOLISM. HEMATOPOIESIS FOLLOWING PHLEBOTOMY. IRON AS A LIMITING FACTOR ${ }^{1}$
}

\author{
By STUART FINCH, ${ }^{2}$ DONALD HASKINS, ${ }^{3}$ aNd CLEMENT A. FINCH 4
}

\author{
(From the Department of Medicine, Harvard Medical School; the Medical Clinic, Peter Bent \\ Brigham Hospital, Boston; and the Radioactivity Center of the Laboratory for \\ Nuclear Science and Engineering, Massachusetts Institute \\ of Technology, Cambridge, Mass.)
}

(Submitted for publication April 1, 1950; accepted, May 8, 1950)

In the studies to be reported, dogs and men were repeatedly phlebotomized over a period of several months. The bleeding produced anemia and thereby stimulated hematopoiesis. The removed blood contained certain materials necessary for production of blood. It was anticipated that red cell stroma, pyrol pigment, and globin would be fabricated with ease while the assimilation of iron would be more limited. Attention was, therefore, directed toward the iron metabolism of the phlebotomized subjects. In individuals with great variation in body iron stores the degree of anemia produced, the mobilization of body iron and the rate of hematopoiesis were calculated. The results are presented to indicate the role which iron plays in hematopoiesis following the loss of blood.

\section{MATERIALS AND METHODS}

Red cell counts were done with calibrated U. S. Bureau of Standards pipettes in duplicate. Hemoglobin was determined colorimetrically by the method of Evelyn (1). Wintrobe tubes were used for hematocrit determinations. Reticulocyte counts were done by the method of Osgood and Wilhelm (2). Serum iron and iron-binding protein were determined as previously reported (3) and bilirubin by the method of Malloy and Evelyn (4). Blood volumes were done using the dye T-1824 according to the method of Gibson and Evelyn with a correction factor as described by Gibson and his associates (5) of 85 per cent.

1 This investigation was supported by a research grant from the Division of Research Grants and Fellowships of the National Institutes of Health, United States Public Health Service, the Office of Naval Research, and the Atomic Energy Commission.

2 Research fellow in Hematology, Peter Bent Brigham Hospital. Present address: Evans Memorial Hospital, Boston.

${ }^{3}$ Research fellow in Hematology, Peter Bent Brigham Hospital, Boston.

4 Associate in Medicine, Harvard Medical School; Associate in Medicine, Peter Bent Brigham Hospital. Present address: University of Washington School of Medicine, Seattle.
Tissue iron analyses were performed by first wet ashing and then determining the iron content colorimetrically using orthophenanthroline as an indicator. Eosinophil counts were done by the direct method as previously reported (6). Exercise tolerance tests were performed according to the standards of the Harvard Fatigue Laboratory (7): In translating grams of hemoglobin into iron a value of $3.3 \mathrm{mgms}$ of iron per gram hemoglobin was assumed.

Blood production was estimated in a fashion similar to the method employed by Whipple and his associates (8). The red cell mass determined weekly and the red cells removed at phlebotomy were measured. Thus, the amount of blood produced per week could at first approximation be expressed as: grams hemoglobin removed by phlebotomy-grams hemoglobin deficit in RBC mass. Such an equation would not take into consideration the normal turnover of red cells within the circulating cell mass. In a mixed cell population this amounts to about one per cent per day of the circulating red cell mass or in the normal adult approximately $350 \mathrm{ml}$ of blood per week. This turnover figure represents the normal rate of hematopoiesis (100 per cent) in man. There is good evidence that newly formed red cells live for a period of 120 days with only slight breakdown through most of this period $(9,10)$. Therefore, as a mixed population is replaced by new cells through phlebotomy and red cell production, the breakdown of erythrocytes should decrease proportionately to the number of new erythrocytes present. In calculating the rate of hematopoiesis, the assumption has been made that the turnover or breakdown of newly formed erythrocytes within the experimental period was negligible. The relative population of new cells versus mixed cells was calculated each week throughout the experimental period and hematopoiesis calculated both on the basis of the hemoglobin balance of the individual and the theoretical turnover of hemoglobin within the red cell mass. A typical calculation of rate of hematopoiesis as applied to Group I-subjects with normal iron stores-is shown in Table I. It will be observed that as a result of phlebotomy and new cell formation the theoretical turnover rate (red cell breakdown and replacement) has fallen from the original 7 per cent to 3.3 per cent at the end of the study. The validity of this second assumption rests on experimental data $(9,10)$. Right or wrong, it does not change the relative differences in rate of hematopoiesis between the various groups of patients studied. 
TABLE I

Calculation of rate of hematopoiesis

\begin{tabular}{|c|c|c|c|c|c|c|c|c|c|}
\hline Week & Hematocrit* & Cell mass* & $\underset{\text { removed }}{R B C}$ & $\begin{array}{l}\text { Deficit in } \\
\text { RBC mass }\end{array}$ & $\underset{\text { RBC† }}{\text { Regenerated }}$ & $\begin{array}{c}\text { Theoretical } \\
\text { RBC } \\
\text { breakdown and } \\
\text { synthesis per wk }\end{array}$ & $\underset{\substack{\mathbf{R B C} \\
\text { turnover } \\
\text { wk }}}{\text { per }}$ & $\begin{array}{l}\text { Combined } \\
\text { regenerated } \\
\text { and turnover } \\
\text { RBC per wk }\end{array}$ & $\begin{array}{c}\text { Rate of } \\
\text { hematopoiesis }\end{array}$ \\
\hline $\begin{array}{r}0 \\
1 \\
2 \\
3 \\
4 \\
5 \\
6 \\
7 \\
8 \\
9 \\
10 \\
11 \\
12 \\
13 \\
14\end{array}$ & $\begin{array}{l}44.5 \\
44.5 \\
39.9 \\
38.9 \\
37.9 \\
36.4 \\
36.3 \\
35.0 \\
33.6 \\
35.1 \\
36.6 \\
38.0 \\
39.6 \\
41.0 \\
42.5\end{array}$ & $\begin{array}{l}2,450 \\
2,450 \\
2,200 \\
2,140 \\
2,096 \\
2,000 \\
1,995 \\
1,925 \\
1,850 \\
1,925 \\
2,019 \\
2,095 \\
2,180 \\
2,250 \\
2,340\end{array}$ & $\begin{array}{l}m l \\
\overline{246} \\
219 \\
214 \\
209 \\
201 \\
200 \\
192\end{array}$ & $\begin{array}{r}- \\
-250 \\
-60 \\
-50 \\
-90 \\
-\quad 5 \\
-70 \\
=75 \\
+73 \\
+94 \\
+76 \\
+85 \\
+70 \\
+90 \\
+\quad 25\end{array}$ & $\begin{array}{l}m l \\
-4 \\
159 \\
164 \\
119 \\
196 \\
130 \\
120 \\
75 \\
94 \\
76 \\
85 \\
70 \\
90 \\
25\end{array}$ & $\begin{array}{c}\text { per cent } \\
7 \\
6.3 \\
5.6 \\
5.1 \\
4.6 \\
4.1 \\
3.7 \\
3.3 \\
3.3 \\
3.3 \\
3.3 \\
3.3 \\
3.3 \\
3.3 \\
3.3\end{array}$ & $\begin{array}{c}m l \\
172 \\
155 \\
137 \\
125 \\
113 \\
101 \\
91 \\
81 \\
81 \\
81 \\
81 \\
81 \\
81 \\
81 \\
81\end{array}$ & $\begin{array}{l}151 \\
296 \\
289 \\
232 \\
297 \\
221 \\
201 \\
156 \\
175 \\
157 \\
166 \\
151 \\
171 \\
101\end{array}$ & $\begin{array}{c}\text { per cent } \\
100 \\
90 \\
173 \\
168 \\
135 \\
173 \\
129 \\
111 \\
91 \\
102 \\
91 \\
96 \\
88 \\
100 \\
67\end{array}$ \\
\hline
\end{tabular}

* Pre-phlebotomy values.

$\dagger$ Calculated from the hematocrit since the blood volume was constant through the experiment.

\section{EXPERIMENTAL PROCEDURE}

\section{Animals}

Two mongrel dogs were selected for phlebotomy. Dog DM had received 2,455 mgms of iron as ferrous ascorbate gelatin intravenously over a period of four months beginning 16 months before the present studies. A liver biopsy was taken at the beginning of the bleeding period. The liver contained $659 \mathrm{mgms}$ of iron per 100 grams of wet tissue by analysis and showed extensive deposits of hemosiderin histologically in both Kupffer and parenchymal liver cells. The animal was then placed on a milk diet for 13 weeks during which period his weight fell from $14 \mathrm{kgms}$ to $10.9 \mathrm{kgms}$. The phlebotomy averaged $344 \mathrm{ml}$ per week over the 12 week period and represented the removal of $1,867 \mathrm{mgms}$ of iron as hemoglobin.

Weekly plasma volume determinations were performed by the dye techniques. At the conclusion of the experimental period, the animal was viviperfused and tissues were analyzed for their iron content and studied histologically. The liver contained $198 \mathrm{mgms}$ of iron or a concentration of $72 \mathrm{mgms}$ of iron per 100 grams of wet tissue. The tissues were gray-green in color at necropsy and histologically showed only very large aggregates of iron, chiefly periportal in location. The iron appeared to be extracellular or, if present within the cell, obscured the normal cell architecture.

Dog DR was a bitch who unexpectedly, in the third week of the experimental period, delivered a litter of normal pups. An initial liver biopsy showed a concentration of $42 \mathrm{mgms}$ of iron per 100 grams of wet tissue. This animal was placed on a milk diet for 14 weeks during which time her weight fell from 8.9 to $5.9 \mathrm{kgms}$. At the conclusion of the bleeding period, the dog was perfused. The liver contained $2.5 \mathrm{mgms}$ of iron per 100 grams of wet tissue or $4.9 \mathrm{mgms}$ of iron in the entire liver. Histological sections showed no evidence of iron.

\section{Studies in man}

The human subjects used for study were arbitrarily divided into five groups. In three of these groups, duplicate blood volume determinations were performed at the onset of the experiment and at intervals through the study with duplicate blood volumes at the termination of study. The amounts of circulating hemoglobin and hemoglobin removed by phlebotomy were determined. Thus, it was possible to calculate the rate of hematopoiesis as previously discussed. A characterization of each of these groups follows :

Group I-Normal iron stores. This group included four healthy young men between the ages of 25 and 30 . In no instance was there any history of blood loss. Dietary intake of iron was calculated as 11, 12, 16 and 20 mgms per day in the individual subjects. ${ }^{5}$ Two of these subjects had taken iron by mouth (CR 200 and AM 400 grams of ferrous sulphate) one and one-half years previously over a six month period. There was no difference in rate of hematopoiesis and no difference in the iron stores as measured by the phlebotomies between these two individuals and the other two normal subjects. It was believed that the oral intake of iron had not produced any appreciable increase in their iron stores, and they were, therefore, included in the normal group. In the latter part of the experiment, supplements including folic acid and protein hydrolysates were given without indication that they accelerated the rate of hematopoiesis.

Group II-Reduced iron stores. Two healthy males (EB and CF), aged 26 and 33, were included in this group. Similar to the subjects in Group I, they showed normal cell indices, normal hematocrits and serum irons at the beginning of the experiment. Both individuals had

5 The dietary histories were taken by Mrs. Casso to whom the authors wish to express their appreciation. 
TABLE II

Blood changes during phlebotomy

\begin{tabular}{|c|c|c|c|c|c|c|c|c|}
\hline & Weeks & HCT* & MCV $\dagger$ & MCHC $\ddagger$ & $\begin{array}{c}\text { Retic- } \\
\text { ulocytes }\end{array}$ & $\underset{\substack{\text { Serum } \\
\text { iron }}}{ }$ & Bilirubin & WBC\& \\
\hline $\begin{array}{l}\text { Group I } \\
\text { Normals }\end{array}$ & $\begin{array}{l}1 \\
2 \\
3 \\
4 \\
5 \\
6 \\
7 \\
8\end{array}$ & $\begin{array}{l}44.5 \\
39.9 \\
38.9 \\
37.9 \\
36.4 \\
36.3 \\
35.0 \\
33.6\end{array}$ & $\begin{array}{l}86 \\
87 \\
88 \\
88 \\
86 \\
83 \\
86 \\
85\end{array}$ & $\begin{array}{l}34 \\
34 \\
34 \\
34 \\
34 \\
35 \\
34\end{array}$ & $\begin{array}{l}1.4 \\
1.2 \\
3.3 \\
2.8 \\
2.4 \\
2.5 \\
2.4\end{array}$ & $\begin{array}{r}100 \\
102 \\
72 \\
55 \\
38 \\
56 \\
38 \\
51\end{array}$ & $\begin{array}{r}1.13 \\
.74 \\
.44 \\
.44 \\
.51 \\
-\end{array}$ & $\begin{array}{l}7.2 \\
7.1 \\
6.9 \\
6.4 \\
5.3 \\
6.6 \\
6.4 \\
6.5\end{array}$ \\
\hline $\begin{array}{l}\text { Group II } \\
\text { Low iron Reserves }\end{array}$ & $\begin{array}{l}1 \\
2 \\
3 \\
4 \\
5 \\
6\end{array}$ & $\begin{array}{l}44.6 \\
39.0 \\
38.4 \\
35.8 \\
33.8 \\
30.4\end{array}$ & $\begin{array}{l}88.5 \\
82 \\
81 \\
89 \\
83.8 \\
84.4\end{array}$ & $\begin{array}{l}32.7 \\
35 \\
34.7 \\
35 \\
35.8 \\
34.3\end{array}$ & $\begin{array}{l}.8 \\
1.8 \\
1.6 \\
2.1 \\
1.4 \\
1.8\end{array}$ & $\begin{array}{l}99 \\
62 \\
60 \\
58 \\
41 \\
37\end{array}$ & $\begin{array}{l}.28 \\
.3 \\
.43 \\
.28 \\
.29\end{array}$ & $\begin{array}{l}5.7 \\
5.7 \\
5.3 \\
5.7 \\
5.2 \\
4.5\end{array}$ \\
\hline $\begin{array}{l}\text { Group III } \\
\text { Iron by mouth }\end{array}$ & $\begin{array}{l}1 \\
2 \\
3 \\
4 \\
5 \\
6 \\
7 \\
8\end{array}$ & $\begin{array}{l}43.7 \\
40.4 \\
38.2 \\
36.8 \\
36.6 \\
39.0 \\
37.9 \\
38.2\end{array}$ & $\begin{array}{l}83.2 \\
86.2 \\
89.4 \\
93.2 \\
90.4 \\
92.8 \\
93.5 \\
91.4\end{array}$ & $\begin{array}{l}35.4 \\
34.8 \\
35.6 \\
33.4 \\
33.6 \\
33.5 \\
32.7 \\
35.7\end{array}$ & $\begin{array}{l}.6 \\
1.3 \\
2.0 \\
2.0 \\
3.6 \\
2.8 \\
4.95 \\
4.4\end{array}$ & $\begin{array}{r}92 \\
95 \\
74 \\
124 \\
78 \\
60 \\
60 \\
87\end{array}$ & $\begin{array}{l}.61 \\
.16 \\
.28 \\
.15 \\
. .12 \\
.24 \\
.32\end{array}$ & $\begin{array}{r}7.4 \\
10.4 \\
9.9 \\
9.9 \\
7.1 \\
5.9 \\
7.9 \\
7.6\end{array}$ \\
\hline $\begin{array}{l}\text { Group IV } \\
\text { Inc. iron Reserves }\end{array}$ & $\begin{array}{l}1 \\
2 \\
3 \\
4 \\
5 \\
6 \\
7 \\
8\end{array}$ & $\begin{array}{l}45.2 \\
39.6 \\
39.0 \\
38.1 \\
38.2 \\
37.8 \\
37.3 \\
37.7\end{array}$ & $\begin{array}{l}87.8 \\
94.3 \\
93.5 \\
91.3 \\
95.7 \\
95.5 \\
97.0 \\
97.0\end{array}$ & $\begin{array}{l}35.8 \\
34.1 \\
33.3 \\
34.8 \\
33.8 \\
35.8 \\
35.1 \\
34.6\end{array}$ & $\begin{array}{r}.8 \\
2.2 \\
2.7 \\
4.1 \\
2.8 \\
4.4 \\
3.3 \\
-\end{array}$ & $\begin{array}{l}234 \\
155 \\
129 \\
169 \\
164 \\
165 \\
163 \\
130\end{array}$ & $\begin{array}{l}.5 \\
.25 \\
.31 \\
.43 \\
.38 \\
.31 \\
-\end{array}$ & $\begin{array}{l}6.9 \\
6.9 \\
6.0 \\
7.9 \\
7.5 \\
6.2 \\
7.8 \\
8.2\end{array}$ \\
\hline $\begin{array}{l}\text { Group V } \\
\text { Hemochromatotics }\end{array}$ & $\begin{array}{l}1 \\
2 \\
3 \\
4 \\
5 \\
6 \\
7 \\
8\end{array}$ & $\begin{array}{l}45.7 \\
42.5 \\
40.6 \\
40.1 \\
40 \\
40.2 \\
41.4 \\
41.2\end{array}$ & $\begin{array}{l}96.7 \\
97 \\
90.1 \\
90.3 \\
94 \\
96.5 \\
94 \\
96.7\end{array}$ & $\begin{array}{l}34.4 \\
35.2 \\
35.8 \\
35.6 \\
34.0 \\
35.5 \\
35.5 \\
35.2\end{array}$ & $\begin{array}{l}2.0 \\
1.2 \\
2.1 \\
2.4 \\
3.6 \\
3.5 \\
3.2 \\
3.3\end{array}$ & $\begin{array}{l}222 \\
201 \\
184 \\
156 \\
167 \\
186 \\
186 \\
173\end{array}$ & $\begin{array}{l}.59 \\
.55 \\
.47 \\
.57 \\
.46 \\
.26 \\
.33 \\
.33\end{array}$ & $\begin{array}{r}7.6 \\
7.1 \\
9.2 \\
10.1 \\
6.9 \\
6.6 \\
8.9 \\
10.5\end{array}$ \\
\hline
\end{tabular}

* HCT-Hematocrit.

$\dagger$ MCV-Mean corpuscular volume in cubic micra.

$\ddagger$ MCHC-Mean corpuscular hemoglobin concentration in per cent.

WBC-White cell count in thousands.

given numerous transfusions over a number of years but not during the six months preceding the study. EB was on a normal diet during the study, while CF was on a milk diet for five weeks to eliminate iron absorption as a factor in hematopoiesis. During the sixth week, CF ate a normal diet with folic acid supplement to exclude dietary deficiency as a possible cause of decreased blood production. This normal diet was not followed by significant reticulocyte or hematocrit rise over a ten day period. It was necessary in both subjects to stop the phlebotomy at the fifth week due to the severity of the anemia produced by phlebotomy. These subjects were later put on iron therapy, 1.2 grams of ferrous sulphate by mouth daily, with an excellent hematologic response.

Group III-Supplementary iron by mouth. Two healthy men between the ages of 25 and 30 were included in this group. They showed a normal hematocrit, normal cell indices and normal serum iron levels. There was no history of previous blood donation or of significant blood loss. These men were given iron by mouth. Subject RC received 0.6 gram of ferrous sulphate per day and WR received 1.2 grams of ferrous sulphate per day. Phlebotomies were conducted over a seven week period.

Group IV-Increased iron stores. Two healthy men, ages 52 and 54, were both brothers of patients with known hemochromatosis. They had no evidence of the disease itself. Their livers were not palpable. They had normal liver function and normal glucose tolerance. However, their serum iron was elevated and their sternal marrow hemosiderin increased, and it was anticipated that they had increased iron stores. Through the experimental period, these men were on a normal diet and were 
phlebotomized weekly for seven weeks. Blood volumes were not performed since in other studies no significant change in blood volume had occurred under the conditions of the experiment.

Group V-Hemochromatosis. Four patients, three men and one woman, were studied. All had a diagnosis of hemochromatosis established by liver biopsy. These patients showed no anemia with the exception of the woman whose hematocrit was 38 . There was a slight macrocytosis. The sternal marrow hemosiderin was increased, and the serum iron elevated with saturation of the iron binding protein. One individual had mild diabetes; the other three did not. Three patients had palpable livers and there was mild liver dysfunction as judged by liver function tests in each instance. All four patients were phlebotomized over a period of seven weeks and in two instances the phlebotomies were continued over a considerably longer period of time. These patients were on a normal diet during the period of study. Blood volumes were performed on only one patient of this group in which instance there was no change through the period of phlebotomy.

\section{RESULTS}

Animal studies. In Figure 1 is shown the hematocrit change in two dogs phlebotomized in relation to the amount of hemoglobin removed.

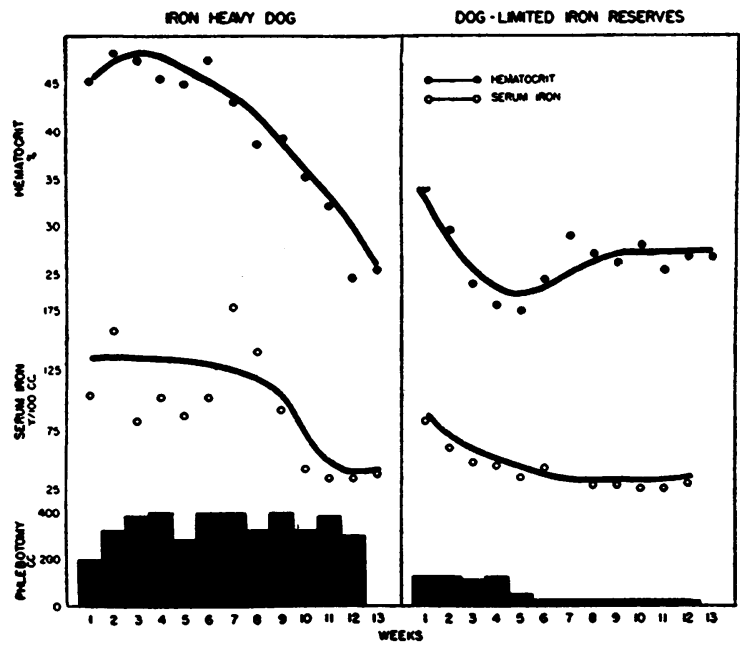

FIG. 1.

Changes in hematocrit and serum iron during bleeding in dog DM with increased iron reserves and $\operatorname{dog} D R$ with limited iron reserves as shown. In dog DM at about the eighth week of bleeding both hematocrit and blood volume decreased abruptly and the serum iron fell. Dog DR tolerated but little bleeding before the characteristic picture of iron deficiency developed with microcytosis and hypochromia of red cells and low serum iron. Retardation of hematopoiesis in both dogs was associated with hypoferremia.

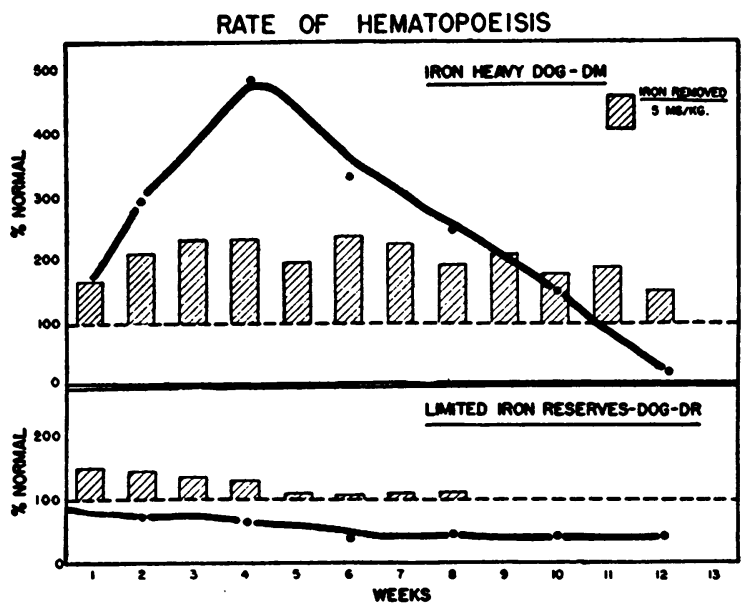

FIG. 2.

The calculated rate of hematopoiesis is shown by the heavy black line. The dotted line at 100 per cent represents the normal rate. Dog DM with increased iron reserves was able to greatly accelerate hematopoiesis for a period of ten weeks following massive bleeding; in dog DR hematopoiesis was progressively depressed throughout the period of observation and anemia was more severe despite the smaller bleedings.

Dog DM with enlarged iron stores, after a lag period during the first week, synthesized between 30 and 60 grams of hemoglobin weekly for seven weeks. During the last four weeks the production of blood was greatly curtailed and the blood volume which had previously fallen from 1,265 to 925 $\mathrm{ml}$ contracted to $580 \mathrm{ml}$. The red cells, which originally showed a mean corpuscular volume of 80 cubic micra and a mean corpuscular hemoglobin concentration of 34 per cent, at the termination of the experiment had a mean volume of 47 cubic micra and a mean corpuscular hemoglobin concentration of 30 . Reticulocytes intially varied between 0.3 and 0.9 per cent. During the period of phlebotomy they were between 1 and 3 per cent; only during the last three weeks when blood production was curtailed (Figures 1 and 2) did they rise to between 3 and 6 per cent. The level of serum iron initially varied between 164 and $282 \mu \mathrm{g}$ per $100 \mathrm{ml}$ with a total serum iron binding capacity of between 423 and $490 \mu \mathrm{g}$ per $100 \mathrm{ml}$. Serum iron remained between 80 and $180 \mu \mathrm{g}$ until the tenth week of bleeding at which time it fell to between 30 and $42 \mu \mathrm{g}$. Dog DR was undoubtedly somewhat iron deficient because of its pregnant state at the beginning of the study. In this animal it was possible to remove only 8 to 14 
grams of hemoglobin per week over the first four weeks and thereafter only a few grams of hemoglobin. The hematocrit fell rapidly to between 25 and 30 per cent and was paralleled by a similar depression in the serum iron and development of a microcytosis. Blood volume decreased from 633 $\mathrm{ml}$ to $403 \mathrm{ml}$ and reticulocytes fell to between 0.2 and 0.7 per cent. The calculated rate of hematopoiesis in these dogs is shown in Figure 2. The dog with excessive iron stores was able to increase blood production to about 500 per cent of normal. The dog with limited iron reserves showed a subnormal blood production throughout the experimental period.

Observations on humans. The hematologic data obtained at weekly intervals through the experimental period are shown in Table II. It will be observed (Figure 3 ) that the degree of anemia produced by the removal of $3,500 \mathrm{ml}$ of blood over a seven week period is proportional to the estimated iron stores. There was no significant change in cell indices in any subject. In Groups

\section{EFFECT OF WEEKY PHEBOTOMY ON HEMATOCRT AND SERUM IRON}
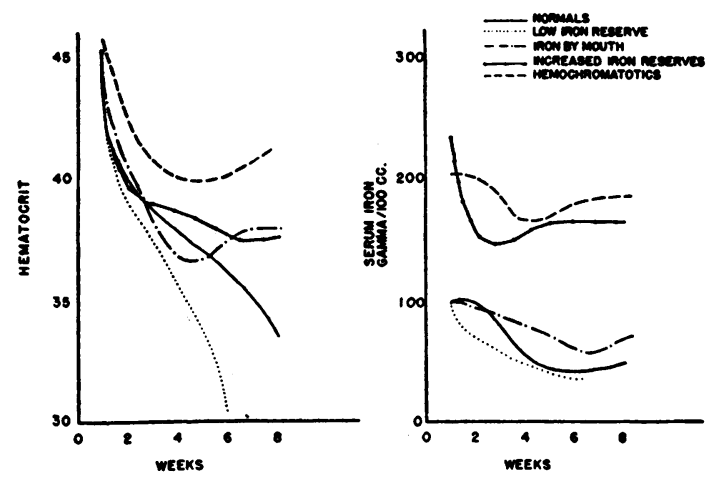

FIG. 3.

The averaged hematocrits and serum iron of each group are shown diagramatically. After a rather uniform fall during the first four weeks, the hematocrits of the various groups in the second month showed different trends. Groups III, IV, and V with adequate available iron maintained their hematocrit, while in normal subjects and individuals with decreased iron reserves it fell rapidly. Serum iron remained elevated in Groups IV and V, while falling in the other groups. In the hemochromatotic, increased iron reserve, and iron by mouth groups the hematocrits were maintained despite continued bleeding. In the normal group and that with decreased iron reserves the hematocrit fell rapidly. Serum iron remained elevated only in the groups with hemochromatosis and increased iron reserves.
I and II there was a progressive fall in serum iron consistent with the development of iron deficiency. In Groups IV and V, there was little evidence of iron deficiency to judge from the consistently elevated serum iron. A slight fall in the serum iron of Group V appeared to be due to a decrease in iron-binding protein rather than to a primary decrease in the serum iron level. The concentration of bilirubin showed a slight decrease, perhaps related to the decreased blood destruction. The high average in the normal group was due to the inclusion of one subject with familial non-hemolytic jaundice. White counts showed no significant deviation from initial levels.

In each group the rate of hematopoiesis was calculated as previously described. Since two of the patients with hemochromatosis in Group V were phlebotomized for considerably longer periods of time, additional data are included relative to this group. It will be observed that in some instances the rate of hematopoiesis was doubled. One would anticipate that the rate of hematopoiesis should be related to the severity of the anemia, provided there was no factor limiting blood production. It is clear from the presented data that the rate of hematopoiesis of the different groups was unrelated to the severity of the anemia.

It was of interest that an average increase of 8 per cent occurred in the blood volume of subjects in Group I between the first to the eighth week despite a progressive anemia. An increase of ten degrees Fahrenheit in the mean daily temperatures through the experimental period for Group I may have influenced the blood volume. The blood volume in Groups II and III showed no significant change. Direct eosinophil counts in Group I were depressed. One subject (SF) showed pitting edema of the ankles despite a normal circulating plasma protein level.

None of the subjects with adequate available iron (Groups III, IV, and V) developed any symptoms relating to the experimental procedure. In Groups I and II, while the hematocrit remained above 40 , there were no symptoms. With hematocrits between 35 and 40 there was some fatigue and decreased tolerance of hot weather. This was of little consequence and probably would not have been noticed except for the attention given the experiment. When the hematocrit fell below 35, conspicuous symptoms were present. There 
TABLE III

Iron removed by phlebotomy in polycythemia vera necessary to maintain a constant hematocrit

\begin{tabular}{lcc}
\hline \hline & $\begin{array}{c}\text { mgms HG iron } \\
\text { removal per day }\end{array}$ & Duration \\
\hline RC & 3.8 & mo. \\
HC & 1.5 & 48 \\
JJ & 2.4 & 60 \\
RZ* & 4.1 & 36 \\
KK & 2.7 & 24 \\
LK & 5.0 & 90 \\
SC & 3.9 & 42 \\
AH & 3.0 & 30 \\
WC & 2.5 & 60 \\
JR & 1.9 & 66 \\
& & 48 \\
\hline
\end{tabular}

* Non-menstruating women.

was some dyspnea on exertion associated with palpitation, excessive sweating, and lack of energy. Individuals at these hematocrit levels avoided strenuous activity. Exercise tolerance tests (7) performed by subjects in Group I showed a subnormal performance and improved after the hemoglobin had returned to normal levels. However, in subject $\mathrm{CF}$, in whom exercise tolerance tests were performed weekly from the beginning of the experiment, it was of interest that even with an hematocrit of 30 the performance was somewhat better than the initial determination.

These subjects, with the exception of $\mathrm{CF}$, were maintained on their usual diet. A certain amount of iron absorbed during the period of study contributed to their available iron stores. If it had been possible to continue bleedings long enough to deplete tissue stores, the amount of bleeding required thereafter to keep a depressed hematocrit would represent the amount of absorbed iron available for hemoglobin production. This is the situation in the patient with polycythemia maintained by phlebotomy after the initial phase of iron depletion. To obtain such data the maintenance phlebotomy requirements of ten patients with polycythemia vera were reviewed ${ }^{\circ}$ (Table III). The first six months were excluded as representing the period of iron depletion. It is assumed that the polycythemic patient is similar to the normal with respect to iron metabolism, except that the bone marrow activity is adjusted at a higher level. An hematocrit of 50 which was maintained through

- Appreciation is expressed to Drs. T. Hale Ham and William Castle for permission to use data which they had collected on five patients with polycythemia vera. phlebotomy in most of these patients should represent a strong stimulus for hemoglobin production. That these patients are iron deficient is born out by the low serum iron and microcytic hypochromic blood cell pictures. In a group of ten such patients there was an average daily absorption of $3.1 \mathrm{mgms}$ of iron, assuming that all of the iron which these individuals absorbed goes into the red cell mass (Table III). The lack of sternal marrow hemosiderin in such patients is consistent with this assumption. It is evident that such a daily absorption amounting to about $175 \mathrm{mgms}$ of iron over the period of eight weeks in which our patients were observed, could contribute relatively little to the 1,200 to $1,500 \mathrm{mgms}$ of iron required to replace that removed by phlebotomy.

\section{DISCUSSION}

In the normal individual the activity of the bone marrow appears to be related to the oxygen capacity of the circulating blood $(11,12)$. By decreasing the circulating level of hemoglobin by phlebotomy, a stimulus is provided for increased hematopoiesis to compensate for the deficiency in oxygen carrying capacity of the blood. This response is dependent on the functional integrity of the bone marrow and the presence of adequate material for building hemoglobin and stroma of red cells. In no instance in our subjects was there evidence of bone marrow dysfunction. An equal stimulus was applied to each subject in terms of the amount of blood removed at weekly intervals. It is, therefore, felt that the variation in individual response is related to the availability of the building materials necessary for blood production.

In these studies iron would appear to be the limiting factor in hematopoiesis. Particular attention should be directed at the animal experiments where the dietary intake of iron was limited, and therefore iron available for hematopoiesis should be dependent solely on the tissue stores of iron. The studies of Whipple and his associates provide excellent background for these studies. In an extensive survey of nutritional factors of importance in hemoglobin production, they have reported that an optimal rate of hemoglobin production by the dog is somewhere between 30 and 60 grams of hemoglobin per week $(13,14)$. It will be observed (Figure 2) that dog DM fell 
within these limits with a weekly production of between 30 and 60 grams of hemoglobin iron from the second to the tenth week of the experiment despite only mild anemia. There is then no reason to believe that the restricted diet curtailed blood production in this animal. A decreased blood production which occurred at the termination of the experiment was associated with a microcytic hypochromic anemia and a low serum iron. If there were factors other than iron limiting hematopoiesis, the serum iron would not be expected to fall. The histological examination of the tissues of this animal would also indicate that intracellular iron was depleted and that only certain large aggregates of iron which may well have been extracellular were left behind. This iron appeared to be relatively unavailable for hemoglobin production. In dog DR with limited iron stores, blood production was severely curtailed, and again the cytological picture of iron deficiency anemia was present. In the human studies, while less severe demands were made on the erythron, curtailment of blood production was associated with a fall in serum iron. There seems little reason to doubt that in each instance a deficiency of iron was the significant factor in limiting blood production.

The rate of return of the hematocrit in the normal group bled $3,500 \mathrm{ml}$ is of interest (Figure 4). Normal hematocrit levels were reached at ap-

EFFECT OF PHLEBOTOMY ON HEMATOCRIT AND SERUM RON

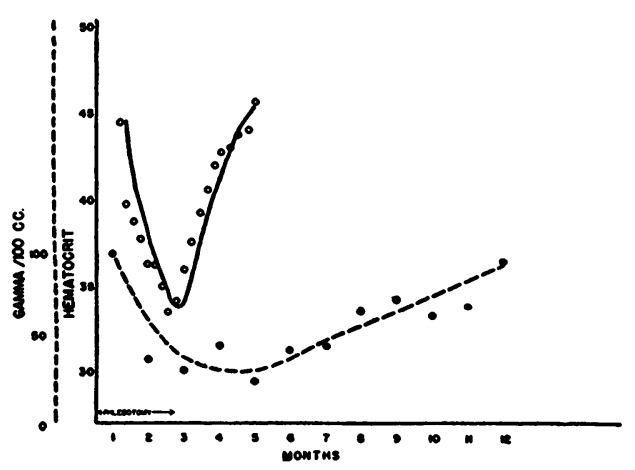

FIG. 4.

This figure represents the average changes in serum iron and hematocrit in the normal group. Approximately $3,800 \mathrm{ml}$ of blood were removed in each subject during the first seven weeks. The hematocrit (solid line) returned to normal during the following two months. Serum iron levels (dotted line) remained depressed through the year.

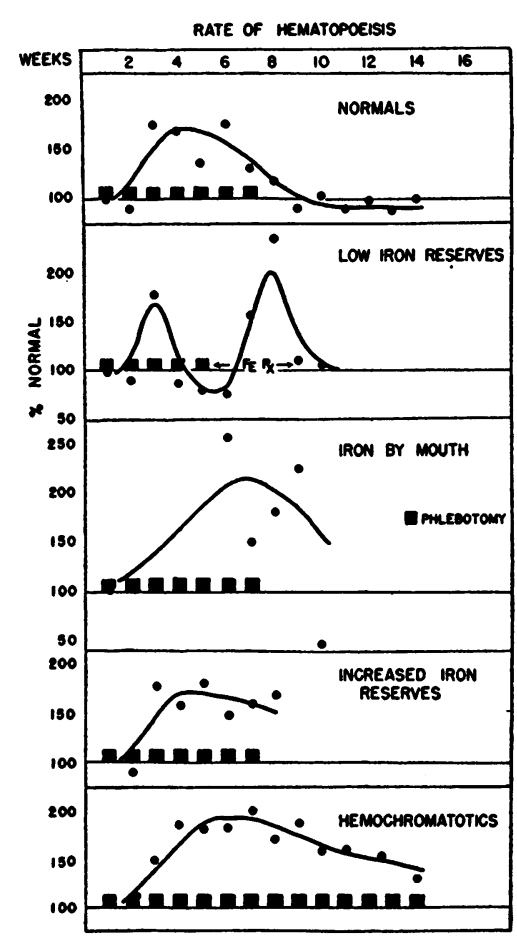

FIG. 5.

The calculated average weekly rate of hematopoiesis in each group is shown by the black dots in this figure. The continuous line indicates the rate of hematopoiesis throughout the experiment. Each solid black square indicates a $500 \mathrm{ml}$ phlebotomy. One hundred per cent represents the normal rate of hematopoiesis. In all groups an initial acceleration in hematopoiesis occurs. In the normal and low iron reserve groups hematopoiesis was soon curtailed despite the development of appreciable anemia. In the low iron reserve group iron therapy subsequently accelerated hematopoiesis. In the other three groups with increased amounts of available iron, hematopoiesis was better sustained. The gradually decreased rate of hematopoiesis, shown particularly in the groups with hemochromatosis, does not represent a decreased rate of replacement of the phlebotomized blood, but reflects the calculated decrease in turnover of red cells within the blood stream.

proximately two months after the termination of bleeding. If new red cells are not destroyed for a period of three to four months, the actual rate of hematopoiesis during this regeneration phase was slightly below normal (Figure 5). It appeared that the period of phlebotomy had not completely depleted iron stores, since in the regeneration phase an average of $10 \mathrm{mgms}$ of iron per day was mobilized for blood formation-exceeding the maximal absorption of iron depleted polycythemic subjects. Such individuals, although able to re- 
place the circulating red cell mass rather rapidly, undoubtedly remained in a relatively iron deficient state for some period of time as judged by the depressed serum iron values over many months (Figure 4).

In considering blood donation, it is of some importance to determine the period of time required to regenerate $500 \mathrm{ml}$ of blood. This is difficult to estimate following a single phlebotomy since the change in hematocrit produced is scarcely more than the daily fluctuation in hematocrit found in man. Following the removal of $500 \mathrm{ml}$ of blood weekly for seven weeks in normal individuals, an equal period of time was required to attain a normal hematocrit. In one patient with hemochromatosis it was possible to continue weekly phlebotomies for over two years with an hematocrit maintained above 40 per cent. In iron depleted patients with polycythemia vera, an average of 88 days are required to replace the red cells removed at one phlebotomy. The emphasis, then, should be placed not on the ability of the bone marrow to reconstitute the red cell mass, but rather on the available iron stores of the individual. Should it be necessary for the individual to absorb dietary iron, perhaps three months or more is needed as in the case of the polycythemic subject. Should there be extensive iron stores, replacement would occur within the week. Estimations in the literature of the recovery rate of blood donors following phlebotomy are consistent with these observations. In healthy normal donors, the deficit is often unrecognizable $(15,16)$ or reported to be almost immediately repleted $(17,18)$. In Chinese donors, many of whom were already anemic, regeneration following phlebotomy was negligible for weeks (19). Intestinal parasitism as well as diet might be complicating factors in the Chinese donors.

Pre-feeding of iron (subjects AM, CR, CF) was not effective in protecting against phlebotomyinduced anemia. On the other hand, the feeding of iron during the period of phlebotomy (Group III) appeared to increase the amount of available iron and rate of hematopoiesis. It seems likely that supplementary iron would allow iron depleted subjects to regenerate blood following phlebotomy at least as rapidly and probably more rapidly than normal subjects.
In man, phlebotomies of $500 \mathrm{ml}$ were well tolerated until the hematocrit fell to a level of approximately 35 per cent. The decrease in hematocrit in the first week averaged 4.5 per cent. Thereafter, changes in hematocrit were related to the ability of the individual to mobilize iron and produce blood. The increased blood production was accompanied by a modest rise in reticulocytes. However, in dog DM where the rate of hematopoiesis was increased as much as five times, reticulocyte levels ranged between $11 / 2$ and 3 per cent. A comparison of such reticulocyte levels (1 to 5 per cent) with those of patients with infection where blood production is greatly curtailed shows the fallacy of attributing any quantitative significance to a reticulocytosis of this degree. The lack of correlation of reticulocytes with blood production may well be related to a variability in reticulocyte maturation time under different conditions (20).

The maintenance of normal blood volumes in our subjects despite anemia is at variance with the studies of Gibson, Harris, and Swigert (21) demonstrating a significant decrease in the blood volume under these circumstances. A significant difference between these two groups of people studied is the clinical state of the individual. $\mathrm{Pa}$ tients studied by Gibson and his coworkers were confined to bed or were very limited in their activity. Our subjects were active and under considerable stress. The low eosinophil counts and the fluid retention with edema despite normal circulating proteins in one subject might suggest that such individuals have a tendency toward fluid retention on the basis of adrenal overactivity.

\section{SUMMARY}

In anemia produced in dogs and man by repeated phlebotomy, the rate of blood regeneration and its relationship to the size of iron stores were studied.

The removal of $3,500 \mathrm{ml}$ of blood in normal subjects over seven weeks resulted in, first, an increased rate of blood formation and later, as iron depletion became manifest, a retardation of hematopoiesis. The subjects while on a normal diet without supplemental iron therapy recovered from their anemia in two months. Serum iron remained depressed, suggesting a deficiency in iron stores over a longer period. 
In other subjects chosen because of their varied iron stores, the rate of hematopoiesis appeared to be determined by the quantity of available iron. In those individuals with depleted stores, hematopoiesis was severely curtailed. In patients with excessive tissue iron, including those with hemochromatosis, blood production continued at an accelerated rate; weekly phlebotomies of $500 \mathrm{ml}$ could be continued for several months without the development of significant anemia.

From data obtained on phlebotomized patients with polycythemia vera, the maximal amount of iron available from diet for hemoglobin production would appear to be 2 to $4 \mathrm{mgms}$ per day. This would contribute but little to the total iron mobilized under the conditions of the experiment.

These observations indicate that the rate of blood regeneration following phlebotomy is dependent chiefly on available body stores of iron.

\section{BIBLIOGRAPHY}

1. Evelyn, K. A., Stabilized photoelectric colorimeter with light filters. J. Biol. Chem., 1936, 115, 63.

2. Osgood, E. E., and Wilhelm, M. M., Reticulocytes. J. Lab. \& Clin. Med., 1934, 19, 1129.

3. Rath, C. E., and Finch, C. A., Chemical, clinical and immunological studies on the products of human plasma fractionation. XXXVIII. Serum iron transport. Measurement of iron-binding capacity of serum in man. J. Clin. Invest., 1949, 28, 79.

4. Malloy, H. T., and Evelyn, K. A., Determination of bilirubin with the photoelectric colorimeter. J. Biol. Chem., 1937, 119, 481.

5. Gibson, J. G., II, Weiss, S., Evans, R. D., Peacock, W. C., Irvine, J. W., Jr., Good, W. M., and Kip, A. F., The measurement of the circulating red cell volume by means of two radioactive isotopes of iron. J. Clin. Invest., 1946, 25, 616.

6. Hills, A. G., Forsham, P. H., and Finch, C. A., Changes in circulating leucocytes induced by the administration of pituitary adrenocorticotrophic hormone (ACTH) in man. Blood, 1948, 3, 755.

7. Brouha, L., Graybiel, A., and Heath, C. W., Step test, simple method of measuring physical fitness for hard muscular work in adult man. Rev. canad. de biol., 1943, 2, 86.
8. Whipple, G. H., and Robscheit-Robbins, F. S., Blood regeneration in severe anemia. I. Standard basal ration bread and experimental methods. Am. J. Physiol., 1925, 72, 395.

9. Shemin, D., and Rittenberg, D., The life span of the human red blood cell. J. Biol. Chem., 1946, 166, 627.

10. Finch, C. A., Wolff, J. A., Rath, C. E., and Fluharty, R. G., Iron metabolism. Erythrocyte iron turnover. J. Lab. \& Clin. Med., 1949, 34, 1480.

11. Tinsley, J. C., Jr., Moore, C. V., Dubach, R., Minnich, V., and Grinstein, M., The role of oxygen in the regulation of erythropoiesis. Depression of the rate of delivery of new red cells to the blood by high concentrations of inspired oxygen. J. Clin. Invest., 1949, 28, 1544.

12. Hurtado, A., Merino, C., and Delgado, E., Influence of anoxemia on the hemopoietic activity. Arch. Int. Med., 1945, 75, 284.

13. Whipple, G. H., and Robscheit-Robbins, F. S., Hemoglobin production factors in human liver; normal, infection and intoxication. J. Exper. Med., 1933, 57, 637.

14. Whipple, G. H., Protein production and exchange in the body including hemoglobin, plasma protein and cell production. Am. J. M. Sc., 1938, 196, 609.

15. Powell, L. D., Blood transfusion; indications and methods. J. Iowa M. Soc., 1926, 16, 180.

16. Cadham, F., Effect on donors of repeated limited blood loss. Canad. M. A. J., 1938, 38, 465.

17. Jones, H. W., Widing, H., and Nelson, L., Blood donors. A study of effect in donors of repeated blood loss. J. A. M. A., 1931, 96, 1297.

18. Martin, J. W., and Myers, J. T., Effects of blood tranfusions on donors. J. Lab. \& Clin. Med., 1935, 20, 593.

19. Snapper, I., Liu, S. H., Chung, H. L., and Yu, T. F., Anemia from blood donation; hematological and clinical study of 101 professional donors. Chinese M. J., 1939, 56, 403.

20. Nizet, A., Nouvelles recherches sur la physiopathologie des hématies. III. Durée de maturation normale des réticulocytes de l'homme in vitro et in vivo. Acta med. Scandinav., 1947, 127, 424.

21. Gibson, J. G., II, Harris, A. W., and Swigert, V. W. Clinical studies of the blood volume. VIII. Macrocytic and hypochromic anemias due to chronic blood loss, hemolysis and miscellaneous causes and polycythemia vera. J. Clin. Invest., 1939, 18, 621. 